\title{
SUCCESSFUL TREATMENT OF MASSIVE PULMONARY EMBOLISM WITH RESCUE FIBRINOLYSIS IN YOUNG PATIENT WITH HOMOCYSTINEMIA - CASE REPORT
}

Irena Mitevska, Irina Kotlar, Emilija Lazarova, Marijan Bosevski University Cardiology Clinic, Skopje, North Macedonia

\section{USPEŠNO LEČENJE MASIVNE PLUĆNE EMBOILJE SA SPAŠAVAJUĆOM FIBRINOLIZOM KOD MLADE PACIJENTKE SA HOMOCISTINEMIJOM - PRIIKAZ SLUCAJA}

Irena Mitevska, Irina Kotlar, Emilija Lazarova, Marijan Bosevski Univerztitetska kardioloska klinika, Skopje, Severna Makedonija

\begin{abstract}
Pulmonary embolism (PE) is the most frequently missed diagnosis in the urgent clinical department with serious consequences. Patients with unprovoked PE have increased risk of recurrent $P E$. Approximately 5 to $8 \%$ of PE patients have inherited thrombophilias. A solated homocystinemia is a rare cause of unprovoked acute pulmonary embolism. Timely diagnosis and proper treatment can prevent complications, costs and mortality and provide patient better quality of life. We are presenting a 42-year-old woman was admitted to our emergency department with the first episode of severe dyspnea and chest pain. She had no history of previous cardiovascular or respiratory disease and no history of previous pulmonary embolism (PE) or deep vein thrombosis (DVT). Urgent echocardiography showed indirect signs of pulmonary embolism which was confirmed by the pulmonary artery CT angiography performed one day after the patient's admission. After two days of heparin infusion, she developed a hemodynamic instability with cardiogenic shock and was treated successfully with fibrinolysis. After the clinical stabilization, she was put on the rivaroxaban therapy, which was recommended for additional six months. The thrombophilia profile was done two weeks after stopping the therapy with rivaroxaban. The thrombophilia panel came back positive for high levels of homocysteine $(67 \mu \mathrm{mol} / \mathrm{L})$, with other thrombophilia results within normal limits. The patient was stable during the follow-up period. Pulmonary embolism should be always suspected in younger patients with acute severe dyspnea even without provocable risk factors. High suspicion level and fast diagnosis are lifesaving. In younger patients presented with unprovoked pulmonary embolism, clinicians should consider inherited prothrombotic factors and homocystinemia as a potential cause. Rescue fibrinolysis is a lifesaving therapy in hemodynamic worsening in intermediate high-risk PE patients. A longer anticoagulation therapy should be considered in these cases with novel oral anticoagulants that are recommended as safer and superior therapy.
\end{abstract} bophilia

Keywords: pulmonary embolism, homocystinemia, throm-

\section{SAŽETAK}

Približno 5 do 8 procenata pacijenata sa plućnom embolijom ima nasledne trombofilije. Četrdesetdvogodišnja žena je primljena na naše odeljenje za prijem urgentnih stanja sa prvom epizodom teške dispneje i bolom u grudima. Nije imala istoriju prethodnih kardiovaskularnih ili respiratornih bolesti niti istoriju prethodne plućne embolije ili duboke venske tromboze. Hitna ehokardiografija je pokazala indirektne znake plućne embolije koja je potvrđena CT angiografijom plućnih arterija urađenoj dan po prijemu pacijenta. Posle dva dana davanja infuzije heparina, pacijentkinja je razvila hemodinamsku nestabilnost sa kardiogenim šokom i lečena uspešno fibrinolizom. Posle kliničke stabilizacije, stavljena je na terapiju lekom Rivaroksaban koji je preporučen u trajanju još dodatnih šest meseci. Profil trombofilije je urađen dve nedelje posle prestanka terapije sa Rivaroksabanom. Panel za trombofiliju je bio pozitivan na visoke nivoe homocisteina (67 $\mu \mathrm{mol} / \mathrm{L})$, uz druge rezultate za trombofiliju koji su bili u okviru normalnih granica. Pacijentkinja je bila stabilna tokom perioda praćenja. Trebalo bi uvek posumnjati na plućnu emboliju kod mlađih pacijenata sa akutnom teškom dispnejom čak i u slučajevima bez provokativnih faktora rizika.Postojanje velike sumnje i brza dijagnoza su bitne za spasavanje života. Kod mlađih pacijenata koji imaju neisprovociranu plućnu emboliju, kliničari bi trebalo da razmotre nasledne protrombotske faktore $i$ homocistinemiju kao jedan potencijalan uzrok. Fibrinoliza može biti terapija koja će spasiti život kod hemodinamskog pogoršanja kod srednje visokorizičnih pacijenata sa plućnom embolijom. Duža antikoagulaciona terapija bi trebalo da bude razmotrena $u$ ovim slučajevima sa novim oralnim antikoagulansima kao preporučenom bezbednom i izvanrednom terapijo.

Ključne reči: plucna embolija, homocistinemija, trombofilija. 


\section{INTRODUCTION}

Pulmonary embolism (PE) is the third vascular cause of death. PE mortality rates exceed $10 \%$ at 30 days and $16 \%$ at 3 months. $5 \%$ of PE patients are presented with a hemodynamic instability and cardiogenic shock which is related tothe high intrahospital mortality (1). Homocysteine is a sulfhydryl amino acid formed from demethylation of dietary methionine. The studies examining the relationship between an elevated plasma homocysteine concentration, have appreciated the relationship between homocysteinemia and venous thrombosis. The elevated level of homocysteine is a risk factor for both arterial and venous thromboembolism (2). The overweight and obese individuals have 2-3-fold increased risk for deep vein thrombosis (DVT) and PE (3). The scientific data also show potential impact of body fat distribution and cardiometabolic abnormalities associated with central obesity with the risk of arterial and venous thrombosis. Venous stasis as a consequence of obesity, may be of more importance for venous thromboembolism (4).

\section{CASE REPORT}

A 42-year-old woman was admitted to our emergency department with the first episode of severe dyspnea and chest pain. She had no history of previous cardiovascular or respiratory disease, no history of PE or DVT. The symptoms started at home one hour before the arrival to our clinic, not provoked by any physical effort. The patient denied any provocable PE risk factors (no history of injury, no surgical treatment, bed rest over $72 \mathrm{~h}$, no cancer history, no signs of DVT or previous PE/DVT). She also denied recent respiratory infection or longer flights. Additionally, we have obtained an information on the contraceptive use five years before this event. She had an increased body weight, with BMI $28 \mathrm{~kg} / \mathrm{m}^{2}$, without other CV risk factors. Physical examination showed tachycardia, tachypnea with a respiratory rate $16 / \mathrm{min}$, without abnormal pulmonary findings and no heart murmurs. ECG showed sinus tachycardia with HR $130 \mathrm{bpm}$, RBBB, and S1Q3T3 sign. Blood pressure was 125/90mmHg. No signs of DVT were found at the clinical examination. The Wells score for PE probability was $<4$ (PE unlikely).

Echocardiography was performed immediately after the emergency department examination in order to evaluate the cause of patient's symptoms. The examination showed an increased right ventricle (RV) size, increased RV to LV ration $>1$, reduced RV function (TAPSE 15 , TDI S' 8 ), presence of McConnell's sign, severe tricuspid regurgitation with dilated non-collapsible v. cava $-21 \mathrm{~mm}$, and signs of pulmonary hypertension (SPAP $54 \mathrm{mmHg}$ ). The LV function was normal, with the left ventricular ejection fraction $65 \%$, and no wall motion abnormalities. There were no thrombus formations weened in the RV cavities or pulmonary artery. Due to the clinical presentation and echocardiography findings of the RV dysfunction and signs of pulmonary hypertension, the patient was admitted to our intensive care unit for suspected PE and the anticoagulation treatment with unfractionated heparin was started.
Laboratory results showed an increased leucocyte level of $11 \times 10^{9} / 1$, Hgb $145 \mathrm{~g} / 1$, hematocrit values 49\%, platelet counts $285 \times 10^{9} / 1$, glomerular filtration rate (GFR) - 98 $\mathrm{ml} / \mathrm{min} / 1.73 \mathrm{~m}^{2}$. Serum electrolytes, renal and liver function tests were within a normal range. hs-Troponin I (ABBOT Essay) was elevated - $182 \mathrm{ng} / \mathrm{l}$ (referent values for women 0$34.2 \mathrm{ng} / \mathrm{l}$ ), D-dimer levels were increased- $9.835 \mathrm{ng} / \mathrm{ml}$ (cut off value $<500 \mathrm{ng} / \mathrm{ml}$ ). Hemostasis findings 4 hours after heparin infusion showed a good therapy response with a prolonged prothrombin time and activated partial thromboplastin time monitoring ( $56 \mathrm{sec})$, INR 1.8 .

Doppler ultrasonography of the lower extremities performed on the second hospital day, showed no signs of DVT.

CT angiography was performed one day after the patient's hospital admission in order to definitely confirm PE. The CT result showed massive pulmonary embolism with riding thrombus over the pulmonary trunk, extending to the right and left pulmonary artery with central filling defects. A large partial-lumen occluding filling defect was noted in the left main pulmonary artery, which was extending further into the hilar branch, occluding the lumen completely. Another larger non-complete lumen occluding filling defect was noted in the right main pulmonary artery. These filling defects were extending into the segmental and sub-segmental branches of the lateral segment of the right middle and bilateral lower lobe. The pulmonary trunk was dilated to $-33 \mathrm{~mm}$. There was no evidence of mediastinal pathology. The evaluated sPESI score was $>1$, which indicated a high 30-day death risk $(10.9 \%)$. Based on the hemodynamic profile, echocardiography findings of the RV dysfunction, sPESI score and elevated troponin levels, the patient was initially assessed at an intermediate high risk for early mortality.

\section{Treatment and complication}

Due to the high probability of PE based on the echocardiography findings, the intravenous heparin therapy was started (7.500 IE iv bolus, with a continued infusion of 30.000 IE/24h). The patient tolerated the treatment well, with a significant dyspnea reduction, the heart rate decreased to 80-90 bpm after three hours, the respiratory rate was $11 / \mathrm{min}$ and $\mathrm{O}_{2}$ saturation $90 \%$ with an oxygen mask. Two days after the admission and Heparin infusion, the patient developed again severe dyspnea, with a hemodynamic instability with BP reduction to $85 / 55 \mathrm{mmHg}$, tachycardia with HR $142 \mathrm{bmp}$, cold and wet periphery, reduction of $\mathrm{O}_{2}$ at room temperature to $81 \%$. Gas analyses showed respiratory acidosis with $\mathrm{pH} 7,32$, increased $\mathrm{pCO}_{2} 53 \mathrm{kPa}, \mathrm{HCO} 325 \mathrm{mEq} / \mathrm{L}$, lactate $2,1 \mathrm{mmol} / \mathrm{l}$. Due to the shock development, the patient was given rescue fibrinolysis with Actilisae 100mg infusion for two hours. The patient hemodynamically stabilized after the first hour of Actilisae infusion, with BP normalization to $110 / 70 \mathrm{mmHg}$, HR $100 \mathrm{bpm}, 0_{2} 89 \%$ on room air. The gas analyses normalized after 4 hours. The patient received heparin infusion for three days after fibrinolysis and continued the management with rivaroxaban with recommended doses of $15 \mathrm{mg} 2 \times 1$ for 21 days than 20mg 1x1 for further six months due to the episode 
of unprovoked PE. The patient was discharged after 10 days, clinically stable, without dyspnea and decreased hs-Troponin values to $45 \mathrm{ng} / 1$.Control echocardiography before the discharge showed normalization of the RV function, reduction of tricuspid regurgitation and no signs of pulmonary hypertension.

\section{Follow-up}

The patient came to the first control after one month. She was asymptomatic, clinically stable and physically active. She did not report side effects from the rivaroxaban therapy. D-dimer values normalized $(325 \mathrm{mg} / \mathrm{l})$. The second control was performed after three months with no echocardiographic signs of the right ventricular dysfunction or pulmonary hypertension. The thrombophilia profile was done two weeks after stopping the therapy with rivaroxaban after six months (factor V Leiden mutation, prothrombin gene mutation, protein C, protein S and AT III activity or deficiency, anti-beta 2 glycoprotein, anticardiolipin antibodies, and serum homocysteine levels). The thrombophilia panel came back positive for high levels of homocysteine $(67 \mu \mathrm{mol} / \mathrm{L})$, with other thrombophilia results within normal limits. Vitamin B12, folate, and vitamin B6 levels were normal.

Figure 1. Admission ECG showed sinus tachycardia with $130 \mathrm{bpm}, \mathrm{RBBB}$ and S1, Q3, T3 pattern

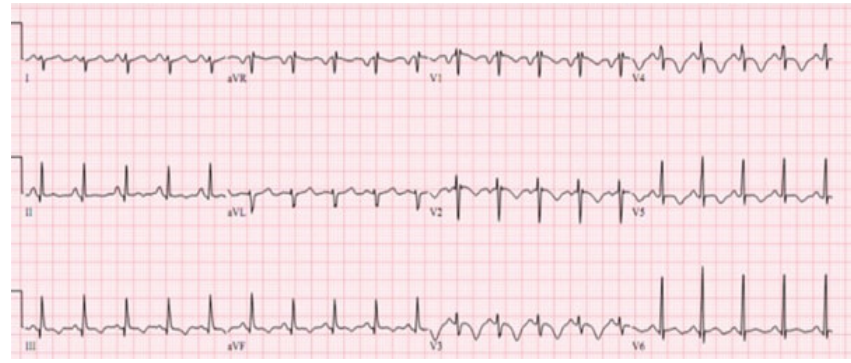

Figure 2.

A. Apical 4 chamber view showing increased right heart cavities with $\mathrm{RV}: \mathrm{LV}$ ratio $>1$;

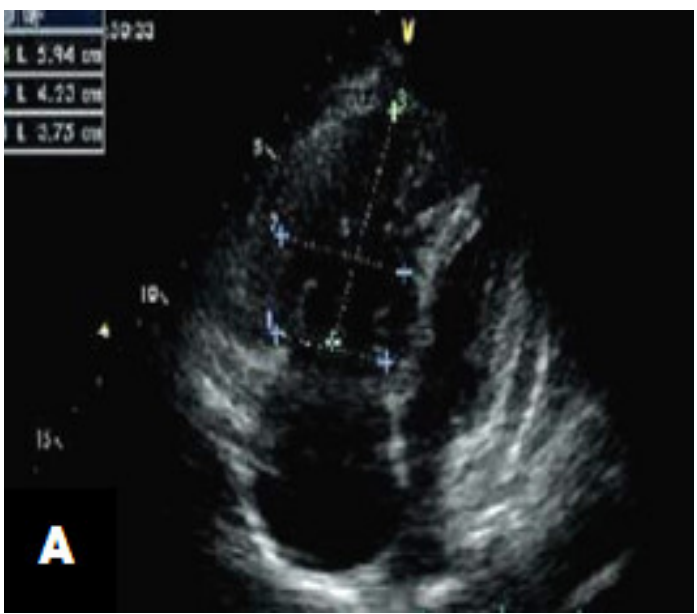

B. Color doppler showing severe tricuspid regurgitation

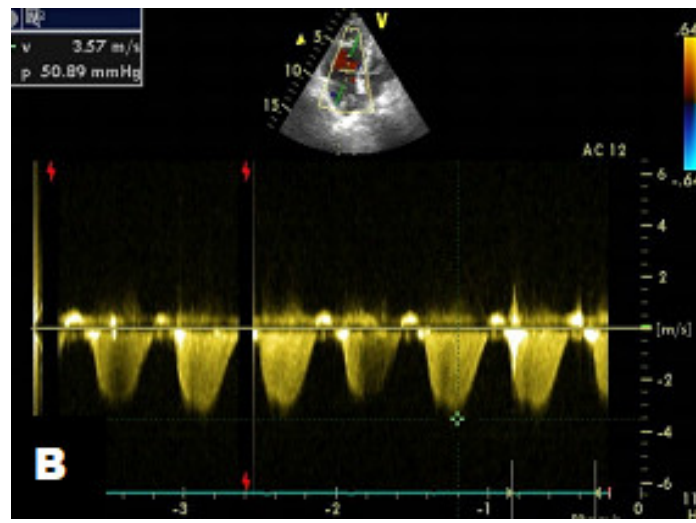

C. Short axis view showing D shaped left ventricle

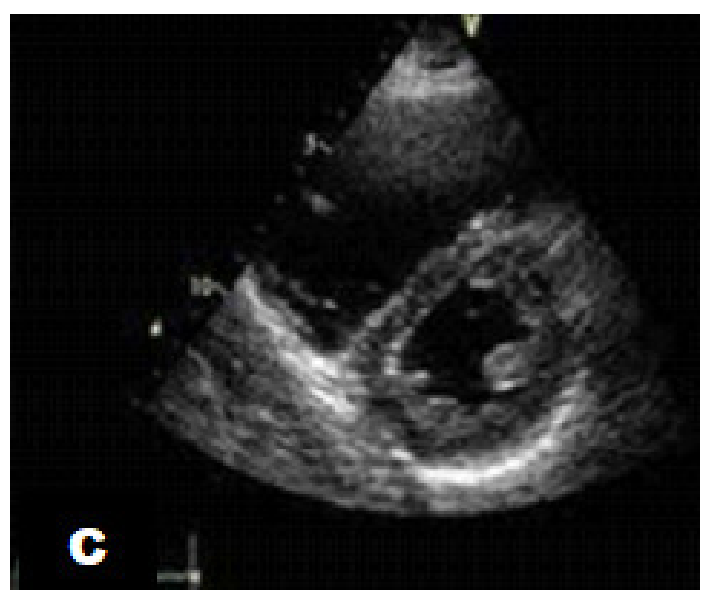

Figure 3. CT angiography of pulmonary artery showing a large partial-lumen occluding filling defect in the left main pulmonary artery, extending further into the hilar branch, occluding the lumen completely. Another larger non-complete lumen occluding filling defect was noted in the right main pulmonary artery.

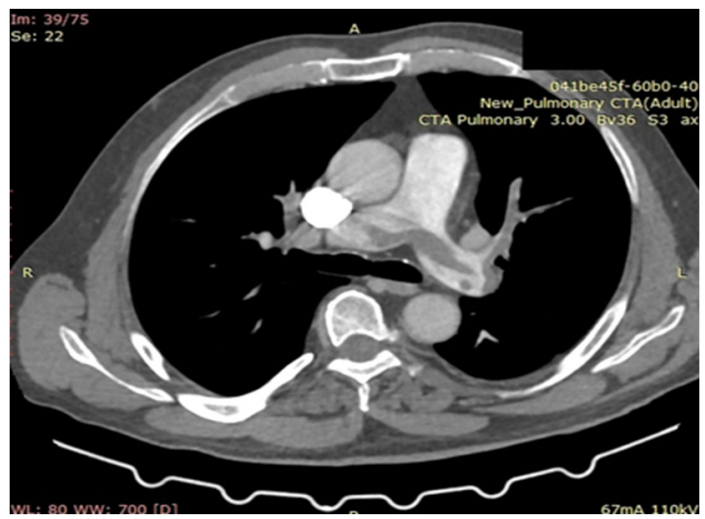




\section{DISCUSSION}

We present the case of a successful treatment of intermediate high-risk PE patient complicated by cardiogenic shock. Although it was the case of massive PE, initially, the underlying etiology was unknown. The final discharge diagnosis of unprovoked VTE was made. The thrombophilia panel testing after discontinuation of the rivaroxaban six-month therapy showed increased blood homocysteine levels. Our patient has an increased body weight, which is a risk for PE. High clinical suspicion is very important for the diagnosis of acute PE in young patients, especially in the absence of history suggestive of DVT or additional provocable risk factors, since this condition is not uncommon and potentially fatal (5). Homocysteine is a sulfhydryl amino acid formed by demethylation of dietary methionin. Homocystinemia is a rare cause of acute pulmonary embolism, which increases a risk of repetitive PE episodes (6). The major acquired factors leading to homocysteinemia are nutritional deficiencies of folate, vitamin B12, and/or vitamin B6, folate antagonist administration (metotrexate, phenytoin), vitamin B6 antagonists (estrogen, theophylline), disturbed renal function, as well as hypothyroidism (6). It is determined by genetic mutations and/or acquired disruption in the homocysteine metabolism pathways. The most frequent genetic causes of homocysteinemia are defects in the gene encoding for enzymes of homocysteine metabolism (the gene encoding for cystatione beta synthase and defects of the gene encoding for methylenetetrahydrofolate reductase e - MTHFR - the most common being MTHFR C677T polymorphism) (7). Homocysteine is known to induce venous thromboembolism (VTE) by multiple mechanisms, including a toxic effect on the clotting cascade, injury to the vascular endothelium and antagonism of the synthesis and function of nitric oxide (8). Any young patient presented with unprovoked PE should have thrombophilia and homocysteine level evaluated,and should have close monitoring for PE, as early recognition of the problem can prevent this serious disease. The normal blood levels of homocysteine range from $5-15 \mu \mathrm{mol} / \mathrm{L}$ (9). Individuals with severe homocysteinemia have the homocysteine concentrations in the range of 50 to $500 \mathrm{ftmol} / \mathrm{L}(10)$. The classification of homocysteinemia is as follows: 1 . moderate risk, 15 to $30 \mu \mathrm{mol} / \mathrm{L}$; 2 . intermediate risk, 30 to $100 \mu \mathrm{mol} / \mathrm{L}$; 3 . severe risk, $>100 \mu \mathrm{mol} / \mathrm{L}$. Our patient had abnormally high homocysteine levels with normal vitamin B12 and folate levels and no abnormalities of other thrombophilia tests. It is necessary to monitor the patient with homocysteinemia carefully due to the high risk of recurrence of thromboembolic events. A case-control study by Falcon et al. found that homocysteinemia was a risk factor for thrombosis in people younger than 40 years (11). Vitamins B6 and B9 or B12 supplements, while they lower the homocysteine level, do not change the risk of heart disease, stroke, or death (12).

Obesity has been consistently reported as a moderate risk factor for venous thrombosis. According to the literature and the MEGA study, the relative risk of venous thrombosis associated with obesity was higher in women than in men (13). The weight gain is associated with an increased risk for cardiovascular disease, diabetes and hypertension, but also with an increased risk for VTE, particularly among obese individuals. The prothrombotic changes in individuals with obesity may contribute to the VTE risk. Several studies have shown that chronic inflammation, assessed by CRP, is associated with obesity. The inflammation stimulates synthesis of factors involved in the coagulation cascade $(14,15)$. The plasma levels of PAI-1, CRP and factor VIII are elevated in obesity, and high levels of these factors have been associated with an increased VTE risk in several studies particularly in women (16).

The patients with PE and cardiogenic shock have the intrahospital mortality rate between $30-60 \%$. Rescue fibrinolysis is a lifesaving treatment in hemodynamically unstable patients $(17,18)$. It also saved the life of our patient, who had favorable clinical and one-year outcome. The latest European Society of Cardiology PE guidelines indicate at least threemonth anticoagulation therapy for patients with unprovoked PE. We decided to follow up our patient yearly and more closely due to an increased risk for repeated PE.

Based on the modified Wells score, our patient was assessed at the admission as low PE probability and managed appropriately. However, this case highlights how the Wells score fails to take into account the risk factors that are commonly known to increase the risk of VTE and change prognosis. In this case, obesity and previous use of oral contraceptive pills were the major risk factors, suggesting that obesity when combined with the oral contraceptive use, ends up with a significant increase of PE risk. The ThromboEmbolism Risk (ESTHER) study by Canonico et al. also indicated that obesity alone or oral estrogen use by itself each increased the risk of VTE by 4.0- and 5.6-fold, respectively; however, OR approached more than 20 -fold when these two risk factors were combined among women who were obese and were taking oral estrogen (19). Obesity and insulin resistance have been reported to increase the risk of VTE in a BMI-dependent manner (20). Rather than the current narrow criteria, a wider range of prothrombotic factors should be considered within the scoring system. Obesity is a known risk factor for VTE, and the data from the Nurses' Health Study found that, among the most obese subjects (body mass index $>35$ ), there was a 6-fold increase in the risk when compared to the normal-weight subjects (21). This same study showed that hypertension and cigarette smoking were also associated with an increased risk of idiopathic PE $(22,23)$. Any scoring system that is used to determine the probability of VTE should include more of the relevant risk factors. Also,the Wells score does not take into account the different gradients in severity of VTE risk factor, instead equating all the included risk factors as similarly influential to the overall score.

\section{CONCLUSION}

We described a successful treatment of massive pulmonary embolism complicated by cardiogenic shock in young overweight woman with homocystinemia. Pulmonary embolism should be always suspected in younger patients with 
acute severe dyspnea even without provocable risk factors. High suspicion level and fast diagnosis are lifesaving. In younger patients presented with unprovoked pulmonary embolism, clinicians should consider inherited prothrombotic factors as a potential cause. Further research is needed to explain the interaction between the genetic markers of thrombophilia, nutritional factors, comorbidities affecting homocysteine metabolism and acquired risk factors for pulmonary embolism. Rescue fibrinolysis is a lifesaving treatment in intermediate risk patients with hemodynamic deterioration.

The patient informed consent form was obtained for the preparation and publication of this case report.

\section{LITERATURE}

1. Konstantinides SV, Meyer G, Becattini C, et al. 2019 ESC Guidelines for the diagnosis and management of acute pulmonary embolism developed in collaboration with the European Respiratory Society (ERS): The Task Force for the diagnosis and management of acute pulmonary embolism of the European Society of Cardiology (ESC). Eur Respir J. 2019 Oct 9;54(3)

2. Den Heijer M, Blom HJ, Gerrits WBJ, Rosendaal FR, Haak HL, Wijermans PW, et al. Is hyperhomocysteinemia a risk factor for recurrent venous thrombosis? Lancet. 1995; 345:882-5.

3. Cushman M. Epidemiology and risk factors for venous thrombosis. Semin Hematol. 2007;44(2):62-69.

4. Genyan Yang, Christine De Staercke, and W. Craig Hooper. The effects of obesity on venous hromboembolism: A review. Open J Prev Med. 2012;2(4):499-509.

5. Bernard Bagattini S, Bounameaux H, Perneger T, Perrier A. Suspicion of pulmonary embolism in outpatients: nonspecific chest pain is the most frequent alternative diagnosis. J Intern Med. 2004 Aug; 256(2):153-60.

6. Herrmann M, Whiting MJ, Veillard A, Ehnholm C, Sullivan DR, Keech AC. Plasma homocysteine and the risk of venous thromboembolism: insights from the FIELD study. Clin Chem Lab Med. 2012;50:2213-9.

7. S. Brustolin, R. Giugliani, and T. M. Félix. Genetics of homocysteine metabolism and associated disorders Braz J Med Res 2010 Jan; 43(1):1-7

8. Radovanovic N, Antonijevic Nm Beletic A et al, Hyperhomocystinemia in patients with pulmonary embolism. Arch. Biol. Sci., Belgrade, 62 (4), 907-914, 2010

9. Ekim M, Ekim H, Keser Yilmaz Y, et al. Study on relationships among deep vein thrombosis, homocysteine and related B group vitamins. Pak J Med Sci. 2015;31(2):398-402.
10. Ganguly P, Alam SF. Role of homocysteine in the development of cardiovascular disease. Nutr J. 2015;14:6

11. Falcon CR, Cattaneo M, Panzeri D, Martinelli I, Mannucci PM. High prevalence of hyperhomocysteinemia in patients with juvenile venous thrombosis. Arterioscler Thromb. 1994;14:1080-3.

12. Sule AA, Chin TJ, Khien H. Recurrent unprovoked venous thromboembolism in a young female patient with high levels of homocysteine. Int J Angiol. 2012;21:95-8.

13. Vučković BA, Cannegieter SC, van Hylckama Vlieg A, Rosendaal FR, Lijfering WM. Recurrent venous thrombosis related to overweight and obesity: re-sults from the MEGA follow-up study. J. Thromb. Haemost, Volume 15, Issue7 July 2017; 1430-1435

14. Blokhin IO, Lentz SR. Mechanisms of thrombosis in obesity. Curr Opin Hematol. 2013;20(5):437-444

15. Stein PD, Beemath A, Olson RE. Obesity as a risk factor in venous thromboembolism. Am J Med. 2005;118:978980

16. Han MS, Jung DY, Morel C, et al. JNK expression by macrophages promotes obesity-induced insulin resistance and inflammation. Science. 2013;339:218-222.

17. Wang TF, Squizzato A, Dentali F, Ageno W. The role of thrombolytic therapy in pulmonary embolism. Blood. 2015;125(14):2191-2199. doi:10.1182/blood-2014-08559278

18. Antithrombotic therapy for venous thromboembolic disease: American College of Chest Physicians EvidenceBased Clinical Practice Guidelines (8th edition). Chest 2008;133(6 Suppl):454S-545S.

19. 19. Canonico M, Oger E, Conard J, Meyer G, Levesque $\mathrm{H}$, Trillot N, et al. Obesity and risk of venous thromboembolism among postmenopausal women: Differential impact of hormone therapy by route of estrogen administration. The ESTHER study. Journal of Thrombosis and Haemostasis. 2006;4:1259-1265.

20. 20. Van Schouwenburg IM, Mahmoodi BK, Veeger NJGM, Bakker SJL, Meijer K, et al. Insulin resistance and risk of venous thromboembolism: Results of a population-based cohort study. Journal of Thrombosis and Haemostasis. 2012;10:1012-1018

21. 21.Wongn $\mathrm{C}$, Moderate risk factor is thromvophilia and obesity is low risk factor.J Investig Med High Impact Case Rep. 2018 Jan-Dec; 6: 2324709617754117.

22. 22.Prandoni P, Bilora F, Marchiori A, et al. An association between atherosclerosis and venous thrombosis. $\mathrm{N}$ Engl J Med 2003; 348:1435-41. 10. Spencer FA, Ginsberg JS, Chong A, Alter DA.

23. 23. The relationship between unprovoked venous thromboembolism, age, and acute myocardial infarction. $\mathrm{J}$ Thromb Haemost 2008;6:1507-13 